\title{
ETHNIC ASPECT OF DIFFERENT CULTURES: PRINCIPLES OF DEVELOPMENT AND FUNCTIONING
}

\author{
(c) Vadim N. Goncharov, Olga Y. Kolosova, Ekaterina Y. Litvinova \\ North-Caucasus Federal University, Krasnodar University of Ministry of Internal Affairs \\ of Russian Federation, Stavropol, Russian Federation \\ science-almanac@mail.ru
}

The functioning of different cultures have common principles. Development is a complex process, the context of development is determined by external factors, and the main role belongs to political, social, ethical and ethnocultural factors. Cultural development takes place through increasing efficiency in the use of natural resources, raising labor productivity and economic specialization. All other aspects of culture that are secondary to them depend on it. Ethnic culture goes through certain stages of development and has its own characteristics, its own development logic, and its own unique development path. The development of culture takes place in the bowels of an ethnic group, in conditions of unconditional substantial ethnic unity. Each culture has its own unique path of development and can be understood only as a historical phenomenon. It is necessary to understand the development of individual cultures, first try to establish the laws of the development of the culture of all humankind. Culture changes through the movement, movement of its elements, and the movement affects objects of material life and ideas: ideology and mythology. In the development of culture, the accumulation, preservation and continuity of cultural traditions, their transmission to subsequent generations is of great importance. The unity of world culture, the common cultural wealth of mankind, determine the presence of similar features and principles of the functioning of various cultures, the existence of patterns, common features in many cultural phenomena, regardless of the place and time of their appearance.

Key words: language, culture, ethnos, personality, polycultural environment, multiculturalism, dialogue.

\section{[В.Н. Гончаров, О.Ю. Колосова, Е.Ю. Литвинова Этнический аспект различных культур: прин- ципы развития и функционирования]}

Функционирование различных культур имеют общие принципы. Развитие - сложный процесс, контекст развития определяют внешние фракторы, и главная роль принадлежит политическим, социальным, этическим и этнокультурным факторам. Культурное развитие происходит посредством возрастающей эфффективности использования природных ресурсов, подъема производительности труда и экономической специализации. От этого зависят все прочие аспекты культуры, вторичные по отношению к ним. Этническая культура проходит определенные этапы развития и имеет свои особенности, свою собственную логику развития, свой собственный уникальный путь развития. Развитие культуры происходит в недрах этноса, в условиях безусловного существенного этнического единства. Каждая культура, имеет свой собственный уникальный путь развития и может быть понятна только как историческое явление. Нужно понять процесс развития индивидуальных культур, прежде пытаться установить законы развития культуры всего человечества. Культура изменяется посредством перемещения, передвижения ее элементов, причем перемещение затрагивает предметы материального быта и идеи: идеологию и мифологию. В развитии культуры большое значение имеет накопление, сохранение и преемственность культурных традиций, их трансляция последующим поколениям. Единство мировой культуры, общность культурного богатства человечества, определяют наличие сходных черт и принципов функционирования различных культур, существование закономерностей, общих черт во многих явлениях культуры, независимо от места и времени их появления.

Ключевые слова: язык, культура, этнос, личность, поликультурная среда, мультикультурность, диалог.

Vadim N. Goncharov - Ph.D. (Advanced Doctorate) in Philosophy, Associate Professor, North-Caucasus Federal University, Stavropol, Russian Federation.

Olga Y. Kolosova - Ph.D. (Advanced Doctorate) in Philosophy, Associate Professor, Krasnodar University of the Ministry of Internal Affairs of the Russian Federation, Stavropol branch, Stavropol, Russian Federation. 
Ekaterina Y. Litvinova - Ph.D. in Pedagogy, Assistant Professor, North-Caucasus Federal University, Stavropol, Russian Federation.

Гончаров Вадим Николаевич - доктор фрилософрских наук, доцент, Северо-Кавказский фредеральный университет, е. Ставрополь, Российская Федерация.

Колосова Ольга Юрьевна - доктор философских наук, доцент, Краснодарский университет Министерства внутренних дел Российской Федерации, Ставропольский фрилиал, е. Ставрополь, Российская Федерация.

Литвинова Екатерина Юрьевна - кандидат педагогических наук, старший преподаватель, Северо-Кавказский федеральный университет, г. Ставрополь, Российская Федерация.

From the point of view of evolutionism, significant changes are constantly occurring in any of the elements of an ethnos, first of all of the language and culture, the development of any cultural element is initially predetermined, its later forms in its infancy are somehow presented in every culture. Development takes place in accordance with stages and steps common to all cultures in the world. There is continuous progress, a straightforward process of transition from simple to increasingly complex.

Supporters of cultural relativism recognize the incompatibility of cultures of different ethnic groups and eras. O. Spengler affirms the uniqueness of each of the cultures. A feature of culture is its originality and uniqueness. "Culture is understood as the inner essence of human ideas ..." [13, pp. 3-9]. "Culture is an essential characteristic of the social sphere of society; it is inseparable from the social activity of man" [5, pp. 74-78]. Each ethnic group makes its own unique contribution to world culture. All cultures are alignable and significant, each enriches the universal and ensures the preservation of the ethnic group.

Diffusionism is based on the idea of the development of culture or various elements of culture as a process of their distribution from one or several centers and has a geographical location. Each of them originated in a particular region and from there spread across the globe.

Functionalism emphasizes that culture serves the needs of the individual, and above all his three basic needs: basic (the need to satisfy various physical needs), derivatives (the needs for the division of labor, for protection, for the regulation of reproduction, for social control) and integrative (needs for psychological security, social harmony, purpose of life, system of knowledge, laws, religion, magic, mythology, art). Culture does not have superfluous and useless elements, it is an integrity in which all its elements are independent, it is a system of objects, actions and attitudes in which all its constituent parts are means for some purpose. All these objects, types of activities and installations are organized to solve vital tasks in the form of institutions: family, clan, community, and tribe. This structure creates the basis for economic cooperation, political and educational activities.

From a dynamic point of view, i.e., considered as a kind of activity, culture can be analyzed in various aspects, such as education, social control, economics, and the system of cognition, beliefs, morality, as well as a way of creative and artistic activity. The cultural process always includes the human factor, which determines the ratio of various types of activity to each other, "... the quality of a person and the ability of social subjects to purposefully interact with the environment" [9, pp. 282-284], "the complex interaction of various types of social communication" [2, pp. 5-10]. People organize cultural elements, interacting with each other in a verbal way or with the help of symbolic actions. Cultural elements, human groups and systems of symbols are the three components of the cultural process. The development of culture has no limits, just as the human experience is endless.

The most perceptible tendencies of modern cultural and civilizational development are multiculturalism and mutual influence (convergence) of cultures. The world is polyphonic and multicultural. The problem of coexistence of various peoples is complex and 
important. Ethnos does not develop on its own - it constantly interacts with other ethnic groups, it is associated with other ethnic groups, economic, spiritual, cultural ties. No people can live in themselves, through themselves and for themselves, but the life of each people represents only a certain participation in the common life of mankind. According to Berry's acculturation theory, group members can demonstrate four types of attitudes in intergroup interaction: integration, assimilation, separation, and marginalization. Culture must constantly not only meet the minimum requirements of environmental conditions, but also carry the necessary potencies to achieve an adaptive effect in new, rapidly changing conditions. The form and degree of expression of the local cultural diversity, depending on the national character, can significantly change at various stages of social development. You can find out the national character by studying the national education system [3, pp. 28-34]. It is necessary to organize a system of upbringing and education based on the scientific study of the forms, methods, directions and mechanisms of personality development [8, pp. 15-18].

For all the diversity of cultures, the variety of cultural models, both in historical retrospective and in the diversity of ethnosocial complexes, ethno-sociocultural differences are inseparable from specific styles of knowledge acquisition, selection and processing of information, largely determined by economic and ethnocultural factors, one way or another determine the socio-cultural development of society [6, pp. 123-128]. For each model of ethnic development, it is important to be defined and consistent with the cultural values of one's people, which, one way or another, form a religious consciousness, "emphasizing the influence of theological ideas on the philosopher ..." [7, pp. 29-31], noting "the influence of Orthodoxy on the formation and design of Russian culture" [10, pp. 39-44]. The cultural-historical imperative is known: unity is possible only in diversity, and diversity can exist only on the basis of unity. Rapprochement and unity are manifested primarily in the material and technical spheres and in the technology of communication, thereby ensuring the development of non-verbal forms of activity and visualization of culture, modern sociality [1, p. 168-177]. The diversity of cultures and their mutual influence cannot but affect the formation of a separate individual and ethnic group as a whole; this is a reality in all societies that contribute to the "dialogue of cultures in the context of the development of modern civilization" [11, pp. 145-160].

The process of development of any culture is associated with acculturation, which is continuous, but a universal human culture, the same for all peoples, is impossible, since all ethnic groups have different accommodating landscapes and different pasts that form the present in time and space. The culture of each ethnic group is unique and it is this mosaicity of humanity as a species that gives it plasticity, due to which the species Homo sapiens survived on planet Earth.

N.Ya. Danilevsky warned that the establishment of world domination of one culturalhistorical type, one culture would deprive mankind of elements of diversity, which would lead to the loss of moral national identity. N.N. Moiseev notes that national cultural unification can only mean the cessation of development. Gigantism is always the beginning of the end. This follows from the law of system optimality. The unity of humankind is similar to the community of organs in organism. Nationalism and separatism are more likely a hidden or overt protest against the unification of public consciousness, against the leveling of national cultures and the suppression of national expression. L. N. Gumilev notes that the only true motto is the sustainable coexistence of peoples in a multi-ethnic state: in the world, but separately. Enmity and bloodshed begin just when people are told that they are the same. The concept of assimilation is opposed by the idea of being equal, but to others, integrated, but respected. 
Recently, an intercultural approach has been actively used: respect, understanding and the correct assessment of diversity; non-discrimination and exclusion; consolidation of solidarity and mutual support between members of multi-ethnic societies. The idea of intercultural cooperation and its importance for the survival of humankind belongs to the category of eternal problems.

From the beginning of the 20th century, the idea of multiculturalism began to develop, which became the fundamental tendency of modern cultural and civilizational development. L. Gurlitt, F. Hansberg, G. Charrelman in this concept included ethnic and world cultures that contribute to the development of universal human consciousness and approve the idea of a single world. According to them, unification of culture is unacceptable. They associated multiculturalism with the freedom of spiritual development of an individual and people: a person cannot deeply and consciously master culture if alien ideas and views are imposed on him, if the development of his natural forces and abilities is not ensured. L. Gurlitt argued that a foreign influence could never be harmful if it is not forcibly and imposed from without, if it does not suppress and obscure the individual traits and original spiritual life of a given people. The modern mental life of peoples is proceeding at such a rate that it is struggling to cope with its most pressing tasks and has no desire to impede its natural development by importing other people's thoughts. The idea of importation contradicts the natural-scientific position that individuals and entire nations develop best when they are presented with the opportunity to grow spiritually independently. We do not regard culture as the opposite of nature, but as its improvement and exaltation and therefore serve it with complete devotion, but serve reasonably. It should give a person the opportunity to develop individually and according to the law that was born with him. In multicultural societies, it is very important what attitude the members of the dominant cultural group demonstrate, because it determines the context and state policy of intercultural interaction.

Multiculturalism is a concept that is more capacious and more appropriate to the principle of dialogue and interaction of cultures that provide "... the upbringing of a positive attitude towards cultural differences" [4, pp. 7-10]. At the psychological level, the policy of active multiculturalism rests on two important points: members of ethnic groups can maintain their ethnic uniqueness; members of ethnic groups feel safe in a multicultural environment.

Dialogue is the only form of coexistence of ethnic cultures and is interpreted not only as a way of interaction of individuals, but also as a means of their relationship with objects, phenomena of culture and art and various cultures in a historical perspective. The principle of dialogue of cultures is based on the philosophical concept of M. M. Bakhtin and is interpreted not only as a way of interaction between individuals, but also as a means of their relationship with objects, phenomena of culture and art, different cultures in a historical perspective that defines historical continuity. Historical continuity as the highest value "... is based on a real presence ... in the human mind" [12, pp. 31-34], is closely connected with historical memory [14, pp. 41-47].

A variety of personalities, an understanding of their specific ethnic characteristics opens the way to mutual understanding of peoples and the dialogue of cultures, which involves not just acquaintance with ethnoculture, but the formation of a personality at the boundary of cultures, able to see someone else through their own and vice versa, which, in turn, is connected with the formation of the ability to compare what is necessary to implement the goals and objectives of ethnocultural education. The dialogue of cultures is updated in the communication of individuals. Without a dialogue of cultures, there is no personality development. On the one hand, the interaction of the individual with objects of another culture, the relationships of the bearers of various cultural orientations make it 
possible to more deeply realize the uniqueness of the spiritual and cultural attainment of their ethnic group; on the other hand, conditions are created for the recognition and understanding of the cultural values of other ethnic groups, the formation of a respectful attitude to other ethnic groups and their representatives. The essence of a certain ethnic culture is known at the borders of cultures. The comprehension of a foreign culture helps to better understand oneself, to better understand the alien through one's own, and one through one's own. Culture in such a dialogue acts as one of the decisive factors for the rapprochement of people.

\section{Лumepamypa}

1. Бакланова О.А., Бакланов И.С. Современная российская социальность в контексте социального конструкционизма // Вопросы социальной теории. 2015. Т. 7. № 1-2. С. 168-177.

2. Бакланова О.А., Бакланов И.С. Контуры типологического исследования социальности современного общества // Известия Саратовского университета. Новая серия. Серия: Философияя. Психология. Педагогика. 2014. Т. 14. № 2-1. С. 510.

3. Говердовская Е.В. Социокультурные и этнологические особенности региона основа модернизации высшего образования на Северном Кавказе // Ученые записки университета им. П.Ф. Лесгафта. 2007. № 7. С. 28-34.

4. Говердовская Е.В. Особенности проектирования образовательного пространства высшей школы в поликультурном регионе // Экономические и гуманитарные исследования регионов. 2014. № 4. С. 7-10.

5. Ерохин А.М. Социально-фрилософфские аспекты развития культурной сферы общества // Экономические и гуманитарные исследования регионов. 2016. № 1. С. 74-78.

6. Ерохин А.М. Научно-информационный аспект исследования социокультурного развития общества в области культуры и искусства // Экономические и гуманитарные исследования регионов. 2015. № 2. С. 123-128.

7. Камалова О.Н. «Созерцание» в философрско-культурологических построениях И. Ильина // Гуманитарные и социально-экономические науки. 2012. № 6. С. 2931.

8. Лобейко Ю.А. Социально-педагогический аспект активности личности в системе общественного развития // Экономические и гуманитарные исследования регионов. 2015. № 1. С. 15-18.

9. Лобейко Ю.А. Социальная активность личности в обществе: социальнопедагогические аспекты формирования // European Social Science Journal. 2014. №7-2(46). С. 282-284.

10. Матяш Т.П., Несмеянов Е.Е. Православный тип культуры: идея и реальность // Гуманитарные и социально-экономические науки. 2015. № 3 (82). С. 39-44.

11. Несмеянов E. Е. «Цивилизация молодых»: идея и реальность // Гуманитарные и социальные науки. 2013. № 6. С. 145-160.

12. Шеффр Г. А., Камалова О. Н. Некоторые аспекты проблемы гносеологического статуса религии в русской религиозной философии: С.Н. Булгаков, П.А. Флоренский, С.Л. Франк // Гуманитарные и социально-экономические науки. 2013. №4 (71). С. 31-34. 
13. Berkovskiy V., Tronina L. Social and historical aspect of interaction of ethnic culture and personality in the context of public development // Научный альманах стран Причерноморья. 2019. № 1 (17). pp. 3-9.

14. Kuleshin M., Leonova N., Nemashkalov P. Historical consciousness as a part of national consciousness: to the problem statement of the research // Научный альманах стран Причерноморья. 2019. №1 (17). pp. 41-47.

\section{References}

1. Baklanova O. A., Baklanov I.S. Sovremennaya rossiyskaya sotsial'nost' v kontekste sotsial'nogo konstruktsionizma. Voprosy sotsial'noy teorii. [Modern Russian sociality in the context of social constructionism. Issues of social theory.] 2015. V. 7. No. 1-2. pp. 168-177 (in Russian).

2. Baklanova O. A., Baklanov I.S. Kontury tipologicheskogo issledovaniya sotsial'nosti sovremennogo obshchestva. Izvestiya Saratovskogo universiteta. Novaya seriya. Seriya: Filosofiya. Psikhologiya. Pedagogika. [Outlines of a typological study of the sociality of modern society. Bulletin of the Saratov University. New episode. Series: Philosophy. Psychology. Pedagogy.]. 2014. V. 14. No. 2-1. pp. 5-10 (in Russian).

3. Goverdovskaya Ye.V. Sotsiokul'turnyye i etnologicheskiye osobennosti regiona - osnova modernizatsii vysshego obrazovaniya na Severnom Kavkaze. Uchenyye zapiski universiteta im. P.F. Lesgafta. [Socio-cultural and ethnological features of the region are the basis for the modernization of higher education in the North Caucasus. Scientific notes of the University. P.F. Lesgaft]. 2007. No. 7. pp. 28-34 (in Russian).

4. Goverdovskaya Ye.V. Osobennosti proyektirovaniya obrazovatel'nogo prostranstva vysshey shkoly v polikul'turnom regione. Ekonomicheskiye i gumanitarnyye issledovaniya regionov. [Features of designing the educational space of a higher school in a multicultural region. Economic and Humanitarian Studies of the Regions]. 2014. No. 4. pp. 7-10 (in Russian).

5. Kamalova O. N. «Sozertsaniye» v filosofsko-kul'turologicheskikh postroyeniyakh I. Il'ina. Gumanitarnyye i sotsial'no-ekonomicheskiye nauki. ["Contemplation" in the philosophical and cultural studies of I. Ilin. Humanitarian and socio-economic sciences]. 2012. No. 6. pp. 29-31 (in Russian).

6. Lobeyko Yu.A. Sotsial'no-pedagogicheskiy aspekt aktivnosti lichnosti v sisteme obshchestvennogo razvitiya. Ekonomicheskiye i gumanitarnyye issledovaniya regionov. [Socio-pedagogical aspect of personality activity in the system of social development. Economic and Humanitarian Studies of the Regions]. 2015. No. 1. pp. 15-18 (in Russian).

7. Lobeyko Y.A. Sotsial'naya aktivnost' lichnosti v obshchestve: sotsial'nopedagogicheskiye aspekty formirovaniya. European Social Science Journal. [Social activity of the individual in society: social and pedagogical aspects of the formation. European Social Science Journal]. 2014. No. 7-2(46). pp. 282-284.

8. Matyash T.P., Nesmeyanov Ye.Ye. Pravoslavnyy tip kul'tury: ideya i real'nost'. Gumanitarnyye i sotsial'no-ekonomicheskiye nauki. [Orthodox type of culture: the idea and reality. Humanitarian and socio-economic sciences]. 2015. No. 3 (82). pp. 39-44 (in Russian).

9. Nesmeyanov Ye.Ye. «Tsivilizatsiya molodykh»: ideya i real'nost'. Gumanitarnyye i sotsial'nyye nauki. ["Civilization of the young": the idea and reality. Humanities and social sciences]. 2013. No. 6. pp. 145-160 (in Russian).

10. Sheff G. A., Kamalova O. N. Nekotoryye aspekty problemy gnoseologicheskogo statusa religii v russkoy religioznoy filosofii: S.N. Bulgakov, P.A. Florenskiy, S.L. Frank. 
Gumanitarnyye i sotsial'no-ekonomicheskiye nauki. [Some aspects of the problem of the epistemological status of religion in Russian religious philosophy: S.N. Bulgakov, P.A. Florensky, S.L. Franc. Humanitarian and socio-economic sciences]. 2013. No. 4 (71). pp. 31-34 (in Russian).

11. Yerokhin A.M. Sotsialno-filosofskiye aspekty razvitiya kulturnoy sfery obshchestva. Ekonomicheskiye i gumanitarnyye issledovaniya regionov. [Socio-philosophical aspects of the development of the cultural sphere of society. Economic and humanitarian studies of the regions]. 2016. No. 1. pp. 74-78 (in Russian).

12. Yerokhin A.M. Nauchno-informatsionnyy aspekt issledovaniya sotsiokul'turnogo razvitiya obshchestva v oblasti kul'tury i iskusstva. Ekonomicheskiye i gumanitarnyye issledovaniya regionov. [Scientific and informational aspect of the study of sociocultural development of society in the field of culture and art. Economic and Humanitarian Studies of the Regions]. 2015. No. 2. pp. 123-128 (in Russian).

13. Berkovskiy $V$., Tronina $L$. Social and historical aspect of interaction of ethnic culture and personality in the context of public development. Science Almanac of Black Sea Region Countries. 2019. No.1 (17). pp. 3-9.

14. Kuleshin M., Leonova N., Nemashkalov P. Historical consciousness as a part of national consciousness: to the problem statement of the research. Science Almanac of Black Sea Region Countries. 2019. No.1 (17). pp. 41-47. 